\title{
Proportion of cancer in a Middle eastern country attributable to established risk factors
}

\author{
Maya A. Charafeddine', Sara H. Olson², Deborah Mukheriji', Sally N. Temraz ${ }^{1}$, Ghassan K. Abou-Alfa² \\ and Ali I. Shamseddine ${ }^{1 *}$
}

\begin{abstract}
Background: Providing an estimate of the percentage of cancer in Lebanon by 2018 that is due to the exposure to risk factors in 2008. Factors include: smoking, body mass index (BMI), physical inactivity, dietary factors, alcohol consumption, infections, and air pollution in adults.

Method: Population Attributable Fraction (PAF) was calculated using the proportion of the population exposed and relative risks for each risk factor from meta-analyses. The PAF estimates the proportion of cases in which exposure may have played a causal role.

Results: Smoking caused most cancer cases, and it will further add a total of 1800 new cases by 2018. Among many other cancers, lung cancer had the largest proportion attributable of around $75 \%$. BMI is expected to increase colorectal, liver and gastric cardia carcinoma specifically in males. High physical activity has a an average of 15\% protection rate on cancer on colorectal cancer. Minimal adherence to Mediterranean diet will affect gastric cancer incidence by $7 \%$. Cases of oropharyngeal and esophageal cancer will be the result of alcohol consumption mainly in males. H.Pylori infection is expected to result in half of the gastric cases by 2018. The high exposure to air pollution is expected to contribute by 13\% to lung cancer cases in 2018.

Conclusion: The highest benefits can be achieved by controlling tobacco smoking. Interrelated and small changes in weight, physical activity and healthy diet with limited alcohol consumption can protect against several Gl cancers in the long run. These results can be used to determine public health interventions that target important risk factors in the general population.
\end{abstract}

\section{Background}

The possibility of developing or dying from cancer is often expressed in population specific incidence and death rates. Alternatively, information on exposure to potential carcinogens over prolonged periods of time can give a glance on the possibility of developing cancer in one's lifetime [1]. The WHO report estimates that around a third of cancers are caused by several leading environmental and behavioral risk factors, specifically tobacco being the biggest culprit among all causative factors [2].

\footnotetext{
* Correspondence: as04@aub.edu.lb

${ }^{1}$ Department of Hematology-Oncology, American University of Beirut Medical Center, P.O Box 11-0236 Riad El Solh, Beirut 1107 2020, Lebanon Full list of author information is available at the end of the article
}

Changes in exposure to risk factors have played a major role in decreasing cancer mortality rates in lung cancer in developed countries, with a decreasing trend following the decreasing smoking pattern [3]. Other pronounced changes in cancer incidence in developed countries were the result of early detection and screening programs such as in colon and breast cancer [4]. In developing countries, however, the previously mentioned cancers are still on the rise, as the adoption of westernized lifestyles is relatively recent compared to developed countries [5]. Migrants' studies revealed that after a few generations, the incidence rate of migrants' population becomes comparable to the host country's population, suggesting that environmental risk factors play a significant role in cancer etiology [5, 6].

Cancer incidence in Lebanon is among the highest in the region and is expected to remain as such over the 
coming decade, according to a recent national epidemiological study and the ministry of health records [7-9]. Around 9000 cases were reported in 2008 and this number has been increasing by $4-5 \%$ annually. Cancer incidence rates are expected to reach 296 and 340 per 100,000 for males and females respectively by 2018 in Lebanon [7], so far the highest recorded cancer incidence among Arab countries. In addition, the World Health Organization estimated 2250 cancer-related deaths in 2012 in Lebanon [10]. While cancer etiology is multifactorial, a set of known risk factors were hypothesized as contributing to the dynamics of cancer epidemiology. The role of specific risk factors will give insight on cancer causation hence providing a quantification of the present risk factors burden [4].

The purpose of this study is to estimate the percentage of cancer in Lebanon that is due to environmental and lifestyle related exposures. Using a new methodologic approach to identify the impact of risk factors in cancer was never performed in the Middle East region, which limited international and regional comparisons. The results can be used to determine public health interventions that target cancer incidence in the general population.

\section{Methods}

Two main components are needed to estimate the role of risk factors in cancer incidence: prevalence of the risk factor in the studied population, and the relative risk of cancer associated with that risk factor. Cancer incidences that are the result of an exposure are presumably related to an accumulation of such exposure over many years, referred to as lag time. A standard latent period of 10 years is considered acceptable for most risk factors [11], although such risk factors are not a point-in-time exposure, many could be present over many years. In this study, the reported exposed population proportion for most risk factors was for 2008; consequently we will estimate the effect of such risk factors on cancer in 2018. The risk factors in this analysis will be restricted to adults.

The selection of risk factors was based on the global health risks report that identified major risk factors that affect disease and mortality. The report identified nine environmental risk factors and seven infectious risk factors that result in nearly half of cancers deaths worldwide [12]. In this report the main risk factors such as smoking, BMI, physical activity, adherence to a healthy Mediterranean diet, and alcohol were included in addition to two other relevant risk factors to the Mediterranean region, including H.Pylori infection and air pollution. All risk factors included in this manuscript are identified as Group 1 carcinogens as per the International Agency for Research on Cancer (IARC), with sufficient evidence in humans [13] (Table 1).
Table 1 Risk factors, exposure levels and studied cancer sites

\begin{tabular}{|c|c|c|c|}
\hline \multirow[t]{2}{*}{ Risk factor } & \multirow[t]{2}{*}{ Exposure level } & \multicolumn{2}{|l|}{ Sources of Data } \\
\hline & & $\begin{array}{l}\text { Prevalence } \\
\text { of exposure }\end{array}$ & Relative Risk \\
\hline $\begin{array}{l}\text { Tobacco } \\
\text { smoking }\end{array}$ & $\begin{array}{l}\text { Current smoker, } \\
\text { former smoker } \\
\text { (cessation } \\
\text { mean } 8.9 \text { years) }\end{array}$ & $\begin{array}{l}\text { Sibai et al. } \\
\text { [14] (WHO) }\end{array}$ & $\begin{array}{l}\text { Lung [42] } \\
\text { Bladder [43] } \\
\text { Larynx [42] } \\
\text { Esophagus [42] } \\
\text { Stomach [42] } \\
\text { Liver [42] } \\
\text { Pancreas [42] } \\
\text { Cervix [42] }\end{array}$ \\
\hline $\begin{array}{l}\text { Body Mass } \\
\text { Index (BMI) }\end{array}$ & $\begin{array}{l}\text { Overweight } \\
(\mathrm{BMl} \geq \\
\left.25 \mathrm{~kg} / \mathrm{m}^{2}\right) \\
\text { Obese } \\
(\mathrm{BMl} \geq 30 \\
\left.\mathrm{kg} / \mathrm{m}^{2}\right)\end{array}$ & $\begin{array}{l}\text { Sibai et al. } \\
\text { [14] (WHO) }\end{array}$ & $\begin{array}{l}\text { Esophageal and } \\
\text { gastric cardia [44] } \\
\text { Colon and Rectal } \\
\text { [45] Liver [46] } \\
\text { Endometrial } \\
{[47,48]} \\
\text { Renal cell [49] } \\
\text { Pancreatic [50] } \\
\text { Ovarian [51] } \\
\text { Breast [29] }\end{array}$ \\
\hline $\begin{array}{l}\text { Physical } \\
\text { Activity }\end{array}$ & $\begin{array}{l}\text { High ( } 7 \text { days } \\
\text { of } 3000 \\
\text { MET-minutes/ } \\
\text { week OR } 3 \\
\text { days of } 1500 \\
\text { MET-minutes/ } \\
\text { week) } \\
\text { Moderate } \\
\text { ( } \geq 3 \text { days } \\
\text { vigorous } \\
\text { intensity, } \\
\text { OR } \geq 5 \text { days } \\
\text { moderate } \\
\text { intensity, OR } \\
\geq 5 \text { days } \geq 600 \\
\text { MET-minutes/ } \\
\text { week) } \\
\text { Low: less than } \\
\text { the moderate } \\
\text { activity }\end{array}$ & $\begin{array}{l}\text { Sibai et al. } \\
\text { [14] (WHO) }\end{array}$ & $\begin{array}{l}\text { Breast [52] } \\
\text { Bladder [53] } \\
\text { Gastroesophageal } \\
\text { [54] } \\
\text { Colorectal [55] }\end{array}$ \\
\hline $\begin{array}{l}\text { Adherence to } \\
\text { Mediterranean } \\
\text { Diet }\end{array}$ & $\begin{array}{l}\text { 9-point scale } \\
\text { adherence to } \\
\text { Mediterranean } \\
\text { diet score } \\
\text { Low: 0-3, } \\
\text { moderate 4-5, } \\
\text { and high 6-9 } \\
\text { points. }\end{array}$ & $\begin{array}{l}\text { Using nationally } \\
\text { representative } \\
\text { dietary intake } \\
\text { data of Lebanese } \\
\text { adults aged } \\
\text { between } 20 \\
\text { and } 55 \text { years } \\
\text { (unpublished data) }\end{array}$ & $\begin{array}{l}\text { Gastric [56] } \\
\text { Colorectal [57] } \\
\text { Bladder [58] }\end{array}$ \\
\hline $\begin{array}{l}\text { Alcohol } \\
\text { consumption }\end{array}$ & $\begin{array}{l}\text { Heavy: More } \\
\text { than } 50 \mathrm{~g} \text { per } \\
\text { day }\end{array}$ & $\begin{array}{l}\text { Sibai et al. } \\
\text { [14] (WHO) }\end{array}$ & $\begin{array}{l}\text { Oropharyngeal } \\
\text { and Esophageal } \\
\text { [59] } \\
\text { Liver [59] } \\
\text { Colon [59] } \\
\text { Breast [59] }\end{array}$ \\
\hline Infection & $\begin{array}{l}\text { Percentage of } \mathrm{H} \text {. } \\
\text { Pylori infections } \\
\text { in the Lebanese } \\
\text { population }\end{array}$ & Naja et al. [17] & Gastric [60] \\
\hline $\begin{array}{l}\text { Air pollution } \\
\left(\mathrm{PM}_{10} \mathrm{PM}_{2.5}\right)\end{array}$ & $\begin{array}{l}\text { Levels exceeding } \\
\text { WHO standards: } \\
\mathrm{PM}_{10}: 20 \mu \mathrm{g} / \mathrm{m}^{3} \\
\mathrm{PM}_{2.5}: 10 \mu \mathrm{g} / \mathrm{m}^{3}\end{array}$ & $\begin{array}{l}\text { Saliba et al. [18] } \\
\text { Saliba et al. [19] }\end{array}$ & Lung [40] \\
\hline
\end{tabular}

MET, Metabolic equivalent of task 


\section{Data sources}

\section{Prevalence of exposures}

In order to study the impact of each risk factor on the studied population, we relied on population based reports or studies involving a representative sample of the Lebanese population that identified the proportion of the population at risk. The World Health Organization report on chronic disease risk factor surveillance specific to Lebanon included a nationally representative sample of Lebanese adults aged between 25 and 64 from randomly selected households using Lebanese Governorates strata [14]. The surveillance study used standardized questionnaires and relied on physical measurements when applicable. Data on common behavioral factors including tobacco smoking, BMI, physical activity and alcohol consumption were stratified in this report by gender for 2008-2009 [14]. Data on adherence to the healthy Mediterranean diet was retrieved from a nationally representative dietary intake data of Lebanese adults aged between 20 and 55 years [15].The Mediterranean Diet Scale (MDS) was constructed to measure adherence to the Mediterranean Diet using 9 components. Individuals were assigned a score of 1 if their consumption of vegetables, legumes, fruits, cereals, and fish was above the sex specific median intake and 0 otherwise. The opposite scoring was given for meat and dairy. For alcohol, men consuming 10-50 g/day and women consuming 5-25 g/day were given a score of 1 and 0 otherwise. Study participants were grouped according to their score: scores ranging from 0 to 3 (low); scores ranging from 3 to 6 (moderate), and scores ranging between 6 to 9 (high) $[16,17]$.

Information on H.Pylori infection among the studied population was retrieved from a nation-wide crosssectional study involving the adult population in Lebanon in 2010 [18]. Numerous studies on air pollution were conducted between 2004 and 2007 measuring particulate matter $\left(\mathrm{PM}_{10}\right.$ and $\left.\mathrm{PM}_{2.5}\right)$ concentrations at different points around Greater Beirut area in Lebanon, in which more than two thirds of the Lebanese population resides [19, 20]. Measurements of air pollution were taken over 1 year for 24 h every 6 days, in a representative heavily populated area with high traffic density in Beirut. The World Health Organization $\mathrm{PM}_{10}$ and $\mathrm{PM}_{2.5}$ annual averages are $20 \mu \mathrm{g} / \mathrm{m}^{3}$ and $10 \mu \mathrm{g} / \mathrm{m}^{3}$ respectively $[19,20]$.

The proportion of the Lebanese population with all the risk factors were reported for 2008, except for air pollution (2004-2007) and H.Pylori infection (2010). Noting that no major changes such as outbreaks occurred in this period, it is safe to assume that this data can be extrapolated for 2008. Table 2 summarizes the prevalence of each of the mentioned risk factors by gender.
Table 2 Prevalence of risk factors in Lebanon in adult males and females aged 25-65 years

\begin{tabular}{|c|c|c|}
\hline Risk Factor & Males & Females \\
\hline \multicolumn{3}{|l|}{ Tobacco smoking, [14] } \\
\hline former smokers & $6.9 \%$ & $3.3 \%$ \\
\hline current smokers & $46.8 \%$ & $31.6 \%$ \\
\hline \multicolumn{3}{|l|}{ Body Mass Index (BMI) [14] } \\
\hline overweight & $30.7 \%$ & $38.9 \%$ \\
\hline obese & $28.7 \%$ & $26.5 \%$ \\
\hline Physical activity, Low activity [14] & $52.4 \%$ & $40.3 \%$ \\
\hline Low adherence to Mediterranean diet [15] & $14.4 \%$ & $12.3 \%$ \\
\hline \multicolumn{3}{|l|}{ Alcohol [14] } \\
\hline Heavy drinkers & $12.0 \%$ & $0.9 \%$ \\
\hline H. Pylori infection* [18] & $52 \%$ & $52 \%$ \\
\hline $\begin{array}{l}\text { Air pollution* }\left(\mathrm{PM}_{10} \text { and } \mathrm{PM}_{2.5}\right. \\
\text { concentrations above allowable levels) }[19,20]\end{array}$ & $85 \%$ & $85 \%$ \\
\hline
\end{tabular}

PM Particulate matter

To complete the analysis, relative risks were retrieved for each risk factor from meta-analyses from epidemiological studies, as shown in Table 1. Meta-analyses are valuable as they represent large populations by pooling the results and identifying patterns from many studies. Criteria for meta-analyses selection included metaanalyses that adopted original articles of case control and cohort studies with an assessment of research quality if available. Assuming that risk related cancers are sufficiently rare, we adopted the use of $O R$ and $R R$ equally. Preference was given for papers including RR stratified by gender and in risk factors' sub-categories used in this article. Relative risks derived from these meta-analyses are shown in Table 3.

\section{Statistical analysis}

To calculate the proportion of cases in which exposure may have played a causal role, we relied on the Population Attributable Fraction (PAF) formula that calculates the proportion by which a cancer would be reduced if a risk factor is eliminated. A gender-specific attributable fraction was calculated using the total prevalence in the total population (aged 25-64 years). The Levin formula, the classic and most common version of the PAF formula, was applied for the study [21].

The formula below is adopted in risk factors with dichotomous variables such as physical inactivity (inactive vs. moderate or highly active population), adherence to Mediterranean diet (low vs. moderate or high adherence), alcohol consumption (high vs. moderate or low), H.Pylori infection (infected population) and in air pollution (exposed population): 
Table 3 Derived relative risks (RR) from meta- analyses used in the PAF estimation

\begin{tabular}{|c|c|c|c|c|}
\hline Risk Factor & Cancer site & Males & Females & References \\
\hline \multirow[t]{8}{*}{$\begin{array}{l}\text { Tobacco smoking } \\
\text { (compared to non-smokers) }\end{array}$} & Esophagus & $\begin{array}{l}\text { Current smokers: } 2.5 \\
\text { Previous smokers: } 2.03\end{array}$ & $\begin{array}{l}\text { Current smokers: } 2.5 \\
\text { Previous smokers: } 2.03\end{array}$ & {$[42]$} \\
\hline & Larynx & $\begin{array}{l}\text { Current smokers: } 6.98 \\
\text { Previous smokers: } 2.31\end{array}$ & $\begin{array}{l}\text { Current smokers: } 6.98 \\
\text { Previous smokers: } 2.31\end{array}$ & {$[42]$} \\
\hline & Lung & $\begin{array}{l}\text { Current smokers: } 8.96 \\
\text { Previous smokers: } 3.85\end{array}$ & $\begin{array}{l}\text { Current smokers: } 8.96 \\
\text { Previous smokers: } 3.85\end{array}$ & [43] \\
\hline & Bladder & $\begin{array}{l}\text { Current smokers: } 3.3 \\
\text { Previous smokers: } 2.0\end{array}$ & $\begin{array}{l}\text { Current smokers: } 3.1 \\
\text { Previous smokers: } 1.65\end{array}$ & {$[42]$} \\
\hline & Stomach & $\begin{array}{l}\text { Current smokers: } 1.64 \\
\text { Previous smokers: } 1.31\end{array}$ & $\begin{array}{l}\text { Current smokers: } 1.64 \\
\text { Previous smokers: } 1.31\end{array}$ & {$[42]$} \\
\hline & Liver & $\begin{array}{l}\text { Current smokers: } 1.56 \\
\text { Previous smokers: } 1.49\end{array}$ & $\begin{array}{l}\text { Current smokers: } 1.56 \\
\text { Previous smokers: } 1.49\end{array}$ & {$[42]$} \\
\hline & Pancreas & $\begin{array}{l}\text { Current smokers: } 1.71 \\
\text { Previous smokers: } 1.18\end{array}$ & $\begin{array}{l}\text { Current smokers: } 1.71 \\
\text { Previous smokers: } 1.18\end{array}$ & {$[42]$} \\
\hline & Cervix & & $\begin{array}{l}\text { Current smokers: } 1.83 \\
\text { Previous smokers: } 1.26\end{array}$ & {$[42]$} \\
\hline \multirow[t]{9}{*}{$\begin{array}{l}\text { Body Mass Index (BMI) } \\
\text { (compared to } \mathrm{BMl} \leq 25 \mathrm{~kg} / \mathrm{m}^{2} \text { ) }\end{array}$} & EGCA & $\begin{array}{l}\text { Overweight:1.71 } \\
\text { Obese: } 2.34\end{array}$ & $\begin{array}{l}\text { Overweight:1.71 } \\
\text { Obese: } 2.34\end{array}$ & [44] \\
\hline & Colon & $\begin{array}{l}\text { Overweight:1.26 } \\
\text { Obese: } 1.71\end{array}$ & $\begin{array}{l}\text { Overweight:1.09 } \\
\text { Obese: } 1.1\end{array}$ & {$[45]$} \\
\hline & Rectum & $\begin{array}{l}\text { Overweight:1.07 } \\
\text { Obese: } 1.75\end{array}$ & $\begin{array}{l}\text { Overweight:1 } \\
\text { Obese: } 1.12\end{array}$ & {$[45]$} \\
\hline & Liver & $\begin{array}{l}\text { Overweight:1.3 } \\
\text { Obese: } 1.8\end{array}$ & $\begin{array}{l}\text { Overweight:1.04 } \\
\text { Obese: } 1.63\end{array}$ & {$[46]$} \\
\hline & Endometrium & & $\begin{array}{l}\text { Overweight:1.02 } \\
\text { Obese: } 1.19\end{array}$ & {$[47]$} \\
\hline & Renal cell & $\begin{array}{l}\text { Overweight:1.22 } \\
\text { Obese: } 1.63\end{array}$ & $\begin{array}{l}\text { Overweight: } 1.38 \\
\text { Obese: } 1.95\end{array}$ & [49] \\
\hline & Pancreas & $\begin{array}{l}\text { Overweight:1.1 } \\
\text { Obese: } 1.5\end{array}$ & $\begin{array}{l}\text { Overweight:1.1 } \\
\text { Obese: } 1.5\end{array}$ & {$[50]$} \\
\hline & Ovary & & $\begin{array}{l}\text { Overweight:1.08 } \\
\text { Obese: } 1.27\end{array}$ & {$[51]$} \\
\hline & Breast & & $\begin{array}{l}\text { Overweight:1.02 } \\
\text { Obese: } 1.19\end{array}$ & [29] \\
\hline \multirow{4}{*}{$\begin{array}{l}\text { Physical Activity (low activity compared } \\
\text { to medium and high activity) Table } 1\end{array}$} & Breast & & Low:1.16 & {$[52]$} \\
\hline & Bladder & Low:1.09 & Low:1.20 & {$[53]$} \\
\hline & Gastric-esophagus & Low:1.15 & Low:1.67 & {$[54]$} \\
\hline & Colon and rectum & Low:1.38 & Low:1.27 & {$[55]$} \\
\hline \multirow{3}{*}{$\begin{array}{l}\text { Adherence to Mediterranean Diet } \\
\text { (low adherence compared to medium } \\
\text { and high adherence) Table } 1\end{array}$} & Stomach & Low adherence:1.49 & Low adherence:1.49 & {$[56]$} \\
\hline & Colon and rectum & Low adherence:1.12 & Low adherence:1.13 & {$[57]$} \\
\hline & Bladder & Low adherence: 1.26 & Low adherence: 1.05 & {$[58]$} \\
\hline \multirow{5}{*}{$\begin{array}{l}\text { Alcohol consumption (High consumption } \\
\text { compared to moderate and low consumption) Table } 1\end{array}$} & Oropharynx & High: 5.30 & High: 5.70 & {$[59]$} \\
\hline & Esophagus & High: 4.69 & High: 8.32 & {$[59]$} \\
\hline & Liver & High: 1.59 & High: 3.89 & [59] \\
\hline & Colon and rectum & High:1.53 & High:1.24 & {$[59]$} \\
\hline & Breast & & High:1.61 & [59] \\
\hline Infection (compared to non-infected patients) & Stomach & Infected with H. Pylori: 2.89 & Infected with H. Pylori: 2.89 & {$[60]$} \\
\hline $\begin{array}{l}\text { Air pollution (exposure to } \mathrm{PM}_{10} \text { and } \mathrm{PM}_{2.5} \text { ) } \\
\text { compared to non-exposed) }\end{array}$ & Lung & $\begin{array}{l}\mathrm{PM}_{10}: 1.08 \\
\mathrm{PM}_{2.5}: 1.09\end{array}$ & $\begin{array}{l}\mathrm{PM}_{10}: 1.08 \\
\mathrm{PM}_{2.5}: 1.09\end{array}$ & [41] \\
\hline
\end{tabular}




$$
\mathrm{PAF}=\mathrm{P}(\mathrm{RR}-1) /(1+\mathrm{P}(\mathrm{RR}-1))
$$

- $\mathrm{P}=$ proportion of population at current exposure level

- $\mathrm{RR}=$ the relative risk at exposure level

The above method expresses the "excess" casesthose that are the result of the risk factor- as a percentage of the total number of the corresponding cancer cases.

Alternatively, in the case where the risk factor presents more than one exposure level, such as in tobacco smoking (ex-smokers, current smokers), and BMI (overweight, obesity), (Table 1), a modified formula of the Levin formula was adopted as follows [22]:

$$
\begin{aligned}
\mathrm{PAF}= & \mathrm{P}_{1}\left(\mathrm{RR}_{1}-1\right)+\mathrm{P}_{2}\left(\mathrm{RR}_{2}-1\right) \\
& / 1+\left(\mathrm{P}_{1}\left(\mathrm{RR}_{1}-1\right)+\mathrm{P}_{2}\left(\mathrm{RR}_{2}-1\right)\right)
\end{aligned}
$$

$\mathrm{P}_{1}$ and $\mathrm{P}_{2}$ denote the population proportion at risk of the first level (overweight) and $\mathrm{P}_{2}$ the population proportion at risk of the second level (obese), with $R_{1}$ and $R R_{2}$ as their respective relative risks. [22]. Excess cases from both levels are aggregated to result in an overall percentage of attributable fractions for each risk factor. The number of cases resulting from these risk factors was further calculated using an estimate of the Lebanese nationals in 2018 [23]. Projected cancer incidence rates for 2018 were multiplied by the corresponding male or female population and further multiplied by the PAF for each cancer site

\begin{tabular}{|c|c|c|c|}
\hline Risk factor & $\begin{array}{l}\text { Percentage attributable risk } \\
\text { factor PAF (\%) in Males in } 2008\end{array}$ & $\begin{array}{l}\text { Projected incident cases in } \\
\text { Lebanon } 2018 \text { (rate per 100,000). } \\
\text { Data from Shamseddine et al. }\end{array}$ & $\begin{array}{l}\text { Number of cases in } 2018 \\
\text { resulting from risk factors }{ }^{a}\end{array}$ \\
\hline \multirow{7}{*}{$\begin{array}{l}\text { Tobacco smoking, former } \\
\text { smokers and current smokers }\end{array}$} & Esophagus: $43 \%$ & 0.6 & 6 \\
\hline & Larynx: 74\% & 7.9 & 129 \\
\hline & Lung: 79\% & 32.7 & 568 \\
\hline & Bladder: 53\% & 41.2 & 480 \\
\hline & Gastric: 24\% & 9.3 & 49 \\
\hline & Liver: 23\% & 7.9 & 40 \\
\hline & Pancreas: $25 \%$ & 5.9 & 32 \\
\hline \multirow{6}{*}{$\begin{array}{l}\text { Body Mass Index (BMI), } \\
\text { overweight and obese }\end{array}$} & Colon: $22 \%$ & 17.1 & 83 \\
\hline & Rectal: 19\% & 4.4 & 18 \\
\hline & Liver: $24 \%$ & 7.9 & 42 \\
\hline & Renal cell: $20 \%$ & N/A & \\
\hline & EGCA: $38 \%$ & N/A & \\
\hline & Pancreatic:15\% & 5.9 & 19 \\
\hline \multirow[t]{4}{*}{ Physical activity, Low activity } & Gastroesophageal: 7\% & N/A & \\
\hline & Colorectal: 17\% & Colon 17.1, Rectal & 80 \\
\hline & & 4.4 & \\
\hline & Bladder: $4 \%$ & 41.2 & 8 \\
\hline \multirow{3}{*}{$\begin{array}{l}\text { Low adherence to } \\
\text { Mediterranean diet }\end{array}$} & Gastric: 7\% & 9.3 & 14 \\
\hline & Colorectal: $2 \%$ & Colon 17.1, Rectal 4.4 & 9 \\
\hline & Bladder: $4 \%$ & 41.2 & 36 \\
\hline \multirow{4}{*}{$\begin{array}{l}\text { Alcohol, } \\
\text { heavy drinkers }\end{array}$} & Oropharyngeal: 34\% & 3.7 & 28 \\
\hline & Esophagus: 31\% & 0.6 & 4 \\
\hline & Liver: 7\% & 7.9 & 12 \\
\hline & Colorectal:6\% & Colon 17.1, Rectal 4.4 & 28 \\
\hline H. Pylori infection & Gastric: 50\% & 9.3 & 102 \\
\hline $\begin{array}{l}\text { Air pollution }{ }^{\mathrm{a}}\left(\mathrm{PM}_{2.5} \text { concentration }\right. \\
\text { above allowable levels) }\end{array}$ & Lung: 13\% & 32.7 & 94 \\
\hline
\end{tabular}
as shown in Tables 4 and 5. Each risk factor was studied

Table 4 Percentage attributable risk factor, relative risk, and actual incidence rates, in Males

above allowable levels)

N/A Data not available

a assuming 4.5 million Lebanese nationals in 2018 
Table 5 Percentage attributable risk factor, relative risk, and actual incidence rates, in Females

\begin{tabular}{|c|c|c|c|}
\hline Risk factor & $\begin{array}{l}\text { Percentage attributable risk factor } \\
\text { PAF (\%) in Females in } 2008\end{array}$ & $\begin{array}{l}\text { Projected incident cases in Lebanon } 2018 \\
\text { (rate per 100,000). Data from Shamseddine et al. }\end{array}$ & $\begin{array}{l}\text { Number of cases in } 2018 \\
\text { resulting from risk factors }\end{array}$ \\
\hline \multirow{8}{*}{$\begin{array}{l}\text { Tobacco smoking, former } \\
\text { smokers and current smokers }\end{array}$} & Esophagus: 33\% & 0.7 & 5 \\
\hline & Larynx: 65\% & 2.0 & 30 \\
\hline & Lung: $72 \%$ & 14.3 & 237 \\
\hline & Bladder: 40\% & 13.4 & 123 \\
\hline & Gastric: 17\% & 7.7 & 30 \\
\hline & Liver: 16\% & 6.6 & 24 \\
\hline & Pancreas: 18\% & 2.3 & 10 \\
\hline & Cervix: $21 \%$ & 5.8 & 28 \\
\hline \multirow{9}{*}{$\begin{array}{l}\text { Body Mass Index (BMI), } \\
\text { overweight and obese }\end{array}$} & Colon: 6\% & 10.9 & 15 \\
\hline & Rectum: 3\% & 5.9 & 4 \\
\hline & Ovary: 9\% & 22.0 & 46 \\
\hline & Liver: $15 \%$ & 6.6 & 23 \\
\hline & Renal cell: 29\% & N/A & \\
\hline & EGCA: 39\% & N/A & \\
\hline & Pancreas: 15\% & 2.3 & 8 \\
\hline & Endometrium: 32\% & N/A & \\
\hline & Breast: $5 \%$ & 137.0 & 158 \\
\hline \multirow[t]{4}{*}{ Physical activity, Low activity } & Breast:6\% & 137.0 & 189 \\
\hline & Gastroesophageal:21\% & N/A & \\
\hline & Bladder: 7\% & 13.4 & 22 \\
\hline & Colorectal: 10\% & Colon 10.9, Rectal 5.9 & 39 \\
\hline \multirow[t]{4}{*}{ Low adherence to Mediterranean diet } & Gastric: $6 \%$ & 7.7 & 11 \\
\hline & Colorectal: $2 \%$ & Colon 10.9, Rectal & 8 \\
\hline & Bladder: 1\% & 5.9 & 3 \\
\hline & & 13.4 & \\
\hline \multirow[t]{5}{*}{ Alcohol, heavy drinkers } & Oropharyngeal: 4\% & 2.8 & 3 \\
\hline & Esophagus: 6\% & 0.7 & 1 \\
\hline & Liver: 3\% & 6.6 & 5 \\
\hline & Colorectal: $1=0.2 \%$ & Colon 10.9, Rectal & 1 \\
\hline & Breast:0.5\% & $\begin{array}{l}5.9 \\
137.0\end{array}$ & 16 \\
\hline H. Pylori infection & Gastric: 50\% & 7.7 & 89 \\
\hline $\begin{array}{l}\text { Air pollution ( } \mathrm{PM}_{2.5} \text { concentration } \\
\text { above allowable levels) }\end{array}$ & Lung: 13\% & 14.3 & 43 \\
\hline
\end{tabular}

individually, knowing that meta-analyses generally use fully adjusted models for potential confounders. Intercorrelation between risk factors or unobserved risk factors was not introduced in this study analyses.

\section{Results}

The analyses shown in Table 4 for males and Table 5 for females estimate the percentage and number of cancer cases that could be reduced for each risk factor 10-years following the exposure time in 2008.
Smoking recorded the highest attributable percentage among all risk factors. Lung and laryngeal cancers in both males and females had the largest proportions attributable, with $79 \%$ and $72 \%$ of lung cancer cases in males and females respectively are the result of smoking. As for the rest of the cancers associated with smoking, the percentages and relative risks were higher in males than in females (Table 4 and Table 5).

Similarly, body mass index (BMI) had a stronger effect on cancer incidence in males than in females. The effect 
of BMI on pancreatic and esophageal and gastric cardia (EGCA) cancer was high comparatively in both genders with $15 \%$ and $38-39 \%$, for pancreatic and EGCA cancers respectively. GI cancers were more prevalent in obese and overweight males compared to females, as shown in liver, colon and rectal cancers (Table 4 and Table 5). High BMI was associated with a third of endometrial cancer and 9\% in ovarian and $5 \%$ in breast cancer.

High physical activity in our study had a less than 20\% protective effect on any of the gastroesophageal, colorectal and bladder cancers in males. Low activity was related to $21 \%$ of gastroesophageal cancer in female cases, and a smaller proportion of $6 \%$ of total breast cancer cases.

Nearly $60-70 \%$ of the Lebanese population moderately adheres to a healthy Mediterranean diet by scoring between 3 and 6 points out of 9 with no significant differences noted across genders or age groups. The minimal adherence to a healthy Mediterranean diet is expected to increase gastric cancer incidence by $6-7 \%$ in both males and females. It was related to a lesser extent to colorectal and bladder cancer in both genders.

Significant differences were noted in the drinking habits of males compared to females. In general, females were non-drinkers or occasional drinkers, while the males were moderate to heavy drinkers (Table 2). Nearly a third of the cases of oropharyngeal and esophageal cancer will be the result of heavy alcohol consumption in males, while it will account for $4 \%$ and $6 \%$ respectively in females. Heavy drinking will result in $7 \%$ and $3 \%$ of liver cancer in males and females respectively, as liver cancer is primarily linked to heavy drinking.

H.Pylori infection was prevalent in half the general Lebanese population in 2010; this is expected to result in $50 \%$ of the Gastric cancer cases in 2018.

Urban pollution is expected to contribute to $13 \%$ of the total lung cancer cases in 2018. According to the studies done in greater Beirut and specific spots at the West Beirut area $[19,20]$, the $\mathrm{PM}_{2.5}$ and $\mathrm{PM}_{10}$ greatly exceeded the WHO standards. The reported concentrations for $\mathrm{PM}_{10}$ and $\mathrm{PM}_{2.5}$ were $63.3 \mu \mathrm{g} / \mathrm{m}^{3}$ and $20.4 \mu \mathrm{g} /$ $\mathrm{m}^{3}$ respectively, exceeding the $20 \mu \mathrm{g} / \mathrm{m}^{3}$ and $10 \mu \mathrm{g} / \mathrm{m}^{3}$ levels set by international standards (Table 1) $[19,20]$. According to the National Health Statistics report in 2012, it is estimated that nearly $85 \%$ of the Lebanese population reside on the coastal and urban areas [24].

As shown in Table 6, the cancer with largest influences by risk factors were lung cancer with $92 \%$ and $85 \%$ of the cases induced by smoking and air pollution for males and females respectively. Upper digestive tract cancers including oropharyngeal, esophageal, and laryngeal with at least $34 \%$ of the cases in males being the result of smoking or alcohol. Influence of risk factors on GI tract cancers was more pronounced in males in colorectal cancer with more than three times higher and cancer nearly twice as high in liver cancer than their female counterparts. Gastric and EGCA cancers were comparable between both genders. Cancer incidence in females was most influenced by smoking as noted in lung cancer (85\%), gastric (73\%), bladder (48\%) and pancreatic (33\%) cancers. Female specific cancers such as breast and ovarian cancers were less influenced by these factors, with the exception of endometrial cancer, for which $32 \%$ were attributable to high BMI.

Based on the estimate of numbers increased due to smoking, the largest increases are expected in laryngeal, lung, and bladder cancers for males, and lung and bladder cancers for females. An expected total of 805 additional cases in 2018 will be the result of smoking. Over 180 cases of colorectal cancer will be due to high BMI and low physical activity in males. In females, high BMI and low physical activity will result in a total of 158 and 189 cases of breast cancer respectively (Tables 4 and 5).

\section{Discussion}

Smoking remains the main culprit in lung cancer incidence due to its high chemical constituent and its impact on health in general. Our results revealed that smoking will add around 1800 cases of cancer including respiratory and GI cancers. Lebanon has one of the highest proportions of smoking in the region in males and the highest in females [25]. A direct link has been established between cigarette smoking, mortality, and lung cancer [26], controlling for genetic and demographic variability. According to a recent epidemiological study in Lebanon by Shamseddine et al. in 2014, the largest increases in cancer incidence by 2018 in Lebanon in males are expected in prostate, bladder, lung, Non-Hodgkin's and colon cancers. As for females, breast, ovary, non-Hodgkin's, lung and colon cancers are expected to mark the highest cancer incidence increases [7]. This projection, in line with our results, showed that smoking-related cancers including bladder and lung mark among the highest expected increases in males and lung for females, further highlighting the legacy of smoking. In addition, our analysis showed that smoking had high influence on rare cancers such as esophageal and laryngeal cancer, with incidence rate of less than 1 and 8 per 100,000 in the Lebanese general population. In addition to cigarette smoking, the WHO report [14] showed that $22 \%$ of the adult population in Lebanon are regular Arguileh (waterpipe) smokers with the majority of them aged less than 35 years, which adds to the burden of respiratory tract cancers in both sexes [14].

Our estimates revealed that over 400 diagnosed cases of GI and breast cancers in 2018 will be caused by overweight and obesity. The proportion of obese and overweight has reached an all-time high. An increase in processed and highly caloric food coupled with a sedentary lifestyle has 
Table 6 Risk factors contribution to specific cancers

\begin{tabular}{|c|c|c|c|}
\hline Cancer site & $\begin{array}{l}\text { PAF (\%) by risk factor } \\
\text { Males Females }\end{array}$ & & Joint hazard of risk factors \\
\hline Oropharyngeal & Alcohol (34\%) & Alcohol (4\%) & \\
\hline Esophageal & Smoking (43\%) Alcohol (31\%) & Smoking (33\%) Alcohol (6\%) & $M(76 \%), F(37 \%)$ \\
\hline Laryngeal & Smoking (74\%) & Smoking (65\%) & \\
\hline Gastroesophageal & Low activity (7\%) & Low activity (21\%) & \\
\hline EGCA & $\mathrm{BMI} \geq 25$ (38\%) & $\mathrm{BMI} \geq 25$ (39\%) & \\
\hline Gastric & $\begin{array}{l}\text { Smoking (24\%) } \\
\text { Low Med diet (7\%), H.Pylori (50\%) }\end{array}$ & $\begin{array}{l}\text { Smoking (17\%) } \\
\text { Low Med diet (6\%), H.Pylori (50\%) }\end{array}$ & M (81\%), F (73\%) \\
\hline Lung & Smoking (79\%), Air pollution (13\%) & Smoking (72\%), air pollution (13\%) & M (92\%), F(85\%) \\
\hline Colorectal & $\begin{array}{l}\text { BMI } \geq 25 \text { (41\%), Low activity (17\%), } \\
\text { Low Med diet (2\%), Alcohol (6\%) }\end{array}$ & $\begin{array}{l}\text { BMI } \geq 25 \text { (9\%), Low activity }(10 \%) \\
\text { Low Med diet ( } 2 \%) \text {, Alcohol }(0.2 \%)\end{array}$ & $M(66 \%), F(21 \%)$ \\
\hline Liver & $\begin{array}{l}\text { BMI } \geq 25 \text { (24\%), Alcohol (7\%), } \\
\text { Smoking (23\%) }\end{array}$ & $\begin{array}{l}\text { BMI } \geq 25 \text { (15\%), Alcohol (3\%), } \\
\text { Smoking (16\%) }\end{array}$ & M (54\%), F(34\%) \\
\hline Bladder & $\begin{array}{l}\text { Smoking (53\%), Low activity (4\%), } \\
\text { Low Med Diet (4\%) }\end{array}$ & $\begin{array}{l}\text { Smoking (40\%), \%), Low activity (7\%), } \\
\text { Low Med Diet (1\%) }\end{array}$ & M (61\%), F(48\%) \\
\hline Pancreas & BMI $\geq 25$ (15\%), Smoking (25\%) & BMI $\geq 25$ (15\%), Smoking (18\%) & $M(40 \%), F(33 \%)$ \\
\hline Renal Cell & $\mathrm{BMI} \geq 25(20 \%)$ & $\mathrm{BMI} \geq 25$ (29\%) & \\
\hline Breast & & $\begin{array}{l}\text { Low activity (6\%) BMI } \geq 25 \text { (5\%), } \\
\text { Alcohol (0.5\%) }\end{array}$ & $F(12 \%)$ \\
\hline Ovarian & & $\mathrm{BMI} \geq 25(9 \%)$ & \\
\hline Endometrial & & $\mathrm{BMI} \geq 25$ (32\%) & \\
\hline Cervix & & Smoking (21\%) & $F(21 \%)$ \\
\hline
\end{tabular}

affected a generation of young adults with increasingly higher BMI [27]. A $5 \mathrm{~kg} / \mathrm{m}^{2}$ increase in BMI was associated with an increase in uterine, gallbladder, kidney and liver cancer mainly [28]. In Lebanon, $27 \%$ of the adult population is obese mostly in those aged over 35 years. High BMI will affect GI cancers, mainly in males, accounting for $41 \%$ of the male colorectal cancer cases and $24 \%$ of liver cancers. In females, our results revealed obesity was associated with a third of endometrial cancer and less with ovarian and breast cancer. Studies showed that other factors, such as reproductive history and menopausal status in the case of breast cancer are likely to influence these female cancers $[29,30]$.

A large number of studies have confirmed the role of physical activity in both sexes through a dose-response association, mainly in colon and breast cancer [31]. No strong evidence was shown between the protective effects of physical activity on other cancers [32]. Domestic chores explain the proportion of higher activity in females over 35 than their male counterparts. Females aged over 25 in Lebanon recorded an average of $121 \mathrm{~min}$ of physical activity, including a combination of walking -moderate or vigorous intensity activities per day, compared to $93 \mathrm{~min}$ for men; however, active men tend to engage in more vigorous types of activities [14]. Our results showed that physical activity influenced gastroesophageal cancer in both sexes yet being a rare cancer the risk reduction is unlikely to make significant changes. The increase in number of breast cancer cases resulting from high BMI and low physical activity is largely explained by the high incidence rate of breast cancer compared to other cancers.

Less than $7 \%$ of cancers studied in our population will be related to low adherence to Mediterranean diet in 2018; this can be explained by the continuing adoption of a healthy diet in the general Lebanese population. A large prospective cohort study including over 28 thousand participants in Greece between 1994 and 1999 showed that a two-point increase in Mediterranean diet adherence scale score was associated with a $12 \%$ decrease in cancer incidence while adjusting for other lifestyle habits [33]. A large review of over 100 case-control studies and a recent report from the American Institute for Cancer Research showed that adherence to Mediterranean diet protected against neoplasms notably in oral cavity, esophagus, stomach, large bowel, larynx, lung and urinary bladder [34].

Potential protection of Mediterranean diet to cancer is increased in low alcohol drinkers as compared to the heavy drinkers [35]. Alcohol acts as an antagonist to folate, necessary for DNA synthesis, thus increasing the risk of cancer in a low-folate diet [36]. Consistent evidence from a review of case control and cohort studies showed a dose-response relationship between alcohol and esophageal, colorectal, breast and liver cancers [34]. Drinking habits in the Lebanese society remain substantially lower than western societies due to social and 
religious conformities. Our data showed that $34 \%$ of the cases of oropharyngeal cancer will be attributable to heavy drinking in males and $4 \%$ in females in 2018. The results reflect the big differences between males and females in drinking habits and quantities consumed.

In 2002, cancers caused by infections were estimated at $17.8 \%$ of the total number of cancers worldwide [37]. The International Agency of Research on Cancer (IARC) identified H. Pylori as a Group I carcinogen and the most common causative agent in infection-related cancers [13]. H. Pylori can manifest as an asymptomatic chronic inflammation, causing stomach cancer and gastric lymphoma in $1-3 \%$ of the infections [38]. It was identified as the strongest risk factor for gastric cancer resulting in $75 \%$ of the total number of cases [39]. A representative sample of the Lebanese population revealed that $52 \%$ of adults were infected with H. Pylori [18]. Half of gastric cancer cases in Lebanon in 2018 are expected to be the result of this infection; higher proportions of $\mathrm{H}$. Pylori are expected in those who are elderly or of low socioeconomic status [18]. Our calculations showed that over 190 gastric cancer cases will be the result of $\mathrm{H}$. Pylori infections.

The IARC have classified PM and outdoor air pollution as a group I carcinogen related to lung cancer [40]. Fine $\mathrm{PM}$ of less than $10 \mu \mathrm{m}-\mathrm{PM}_{10}$ are more hazardous as they can penetrate and adhere to lung tissues more naturally. They are estimated to cause about $7 \%$ of total mortality of trachea, bronchus and lung cancers worldwide [40]. Growing urban population, an inefficient transport system and an inadequate national electrical power system lead to serious pollution concerns in the Middle East [41].

Currently, no trials are ongoing to assess the influence of a multitude of risk factors on cancers in our region to understand the high cancer incidence reported in Lebanon compared to its neighboring countries. Exposure to risk factors is complex and has indirect implications to different diseases; thus eliminating certain exposure now does not imply a drop in cancer cases by 2018. Past exposures keep residual effect over years such as smoking, diet, $\mathrm{H}$. Pylori infection, and air pollution. Our PAF estimates lack confidence intervals as they are difficult to obtain and are beyond the scope of this paper. Results of this report showed that the highest benefits can be achieved by controlling tobacco smoking; as shown, at least two-thirds of the proportion of respiratory cancers can be reduced if smoking is eliminated.

Campaigns targeting the young population will impact smoking in general; it was revealed that the average age at smoking onset in the Lebanese population is 18 years [14]. Limited alcohol consumption would help decrease the upper GI tract cancers as shown earlier. Due to the relatively low prevalence of alcohol consumption, alcohol control in Lebanon is still indirect; thus imposing high taxes on such products and issuing stricter laws concerning drinking and driving would help limit uncontrolled drinking. The risk factors included in this study are interrelated; thus while controlling for one risk factor, an individual can be protected against other related risk factors. As an example, adherence to Mediterranean diet results in lower BMI and less alcohol, that is by just controlling diet. Due to the recent adoption of a westernized lifestyle, the new generation is more exposed to processed food; therefore awareness campaigns in schools and by general practitioners or pediatricians could help restrain this unhealthy lifestyle for both parents and children. Parents are working longer hours; in fact Lebanon has the highest female proportion in the job market compared to the Arab world, with around $31 \%$ being employed [14]. This suggests that children will increasingly depend on school lunches. A control on eating habits can be done through public health authorities imposing healthy meals for children in their schools. Another agenda item for school would be to target sedentary lifestyle among kids, by increasing outdoor activities as part of the educational curriculums. Pollution in Beirut has been increasing due to the centralization and agglomeration around the capital; cleaner gasoline and organized public transport can help reduce the smoke. The ministry of public health is ensuring access to clean water and encouraging basic sanitation habits which will further decrease H. Pylori infections.

\section{Conclusions}

For efficient reduction of cancer incidence, our results show that smoking and obesity are the main risk factors to target; this will have the largest influence in controlling incidence across many cancers. The expected $\mathrm{H}$. Pylori infection reduction will eventually result in a decrease in infection- related cancers. On the other hand, targeting diet, physical activity and pollution would have a lesser and indirect impact. However, the challenges around implementing strict laws in addition to economic and political issues in Lebanon are expected to result in slow progress over the next decade.

\section{Abbreviations}

BMI: Body Mass Index; EGCA: Esophageal and gastric cardia; GI: Gastro intestinal; PAF: Population Attributable Fraction; $\mathrm{PM}_{10}$ or $\mathrm{PM}_{2.5}$ : Particulate matter; RR: Relative Risk; WHO: World Health Organization

\section{Funding \\ SHO and GKA are supported by U.S. National Cancer Institute P30CA008748, C. Thompson PI. No other funding sources were required.}

\section{Availability of data and materials}

Initial raw data from the Lebanese population with the risk factors mentioned in this manuscript are publicly available on this site: $\mathrm{http} / / \mathrm{ww} w$.who.int/chp/ steps/2008_STEPS_Lebanon.pdf

\section{Authors contributions}

$M C$ the first author carried out most of the writing, did the full analysis, and main literature review of this article. SO helped in drafting and editing the text and references, in addition SO consulted on the analysis and the epidemiology concepts. DM, ST and GA edited the manuscript, and checked data consistency 
and related Tables. AS edited the manuscript and added discussion points in the final section. All authors read and approve the final manuscript.

\section{Competing interests}

Authors declare that they have no competing interest.

\section{Consent for publication}

Not applicable. This study involves national data on the Lebanese population.

\section{Ethics approval and consent to participate}

Not applicable. This study involves already available national data on the Lebanese population.

\section{Publisher's Note}

Springer Nature remains neutral with regard to jurisdictional claims in published maps and institutional affiliations.

\section{Author details}

${ }^{1}$ Department of Hematology-Oncology, American University of Beirut Medical Center, P.O Box 11-0236 Riad El Solh, Beirut 1107 2020, Lebanon. ${ }^{2}$ Memorial Sloan-Kettering Cancer Center, Memorial Sloan Kettering Cancer Center, 300 East 66th Street, New York, NY 10065, USA.

Received: 23 February 2016 Accepted: 25 April 2017

Published online: 18 May 2017

\section{References}

1. Seidman H, Silverberg E, Bodden A. Probabilities of eventually developing and of dying of cancer (risk among persons previously undiagnosed with the cancer). CA Cancer J. Clin. 1978;28(1):33-46.

2. Ezzati MDG, Vander Hoorn S, Begg S, Voz T. GLOBAL HEALTH RISKS: mortality and burden of disease attributable to selected major risks. Geneva: World Health Organization; 2009. Contract No.: 26 April 2016.

3. Tyczynski JE, Bray F, Parkin DM. Lung cancer in Europe in 2000: epidemiology, prevention, and early detection. Lancet Oncol. 2003;4(1):45-55.

4. Danaei G, Vander Hoorn S, Lopez AD, Murray CJ, Ezzati M. Causes of cancer in the world: comparative risk assessment of nine behavioural and environmental risk factors. Lancet. 2005;366(9499):1784-93.

5. Jemal A, Center MM, DeSantis C, Ward EM. Global patterns of cancer incidence and mortality rates and trends. Cancer epidemiology, biomarkers \& prevention : a publication of the American Association for Cancer Research, cosponsored by the American Society of Preventive Oncology. 2010;19(8):1893-907.

6. McMichael AJ, Bonett A, Roder D. Cancer incidence among migrant populations in South Australia. Med. J. Aust. 1989;150(8):417-20.

7. Shamseddine A, Saleh A, Charafeddine M, Seoud M, Mukherji D, Temraz S, et al. Cancer trends in Lebanon: a review of incidence rates for the period of 2003-2008 and projections until 2018. Popul. Health Metrics. 2014;12(1):4.

8. Ko HJ, Youn $\mathrm{CH}$, Kim HM, Cho YJ, Lee GH, Lee WK. Dietary magnesium intake and risk of cancer: a meta-analysis of epidemiologic studies. Nutr. Cancer. 2014;66(6):915-23.

9. Shamseddine A, Sibai AM, Gehchan N, Rahal B, El-Saghir N, Ghosn M, et al. Cancer incidence in postwar Lebanon: findings from the first national population-based registry, 1998. Ann. Epidemiol. 2004;14(9):663-8.

10. Ferlay J, Steliarova-Foucher E, Lortet-Tieulent J, Rosso S, Coebergh JW, Comber $\mathrm{H}$, et al. Cancer incidence and mortality patterns in Europe: estimates for 40 countries in 2012. Eur. J. Cancer. 2013:49(6):1374-403.

11. Parkin DM, Boyd L, Walker LC. 16. The fraction of cancer attributable to lifestyle and environmental factors in the UK in 2010. Br. J. Cancer. 2011. 105(Suppl 2):S77-81.

12. Global health risks: mortality and burden of disease attributable to selected major risks, (2009).

13. Cancer IAfRo. IARC Monographs on the evaluation of carcinogenic risks to humans 2016 [26 April 2016]. Available from: http://monographs.iarc.fr/ENG/ Classification/.

14. Sibai A, Hwalla N (2010). WHO STEPS chronic disease risk factor surveillance: data book for Lebanon. Beirut, World Health Organization, American University of Beirut [26 April 2016]. Available from: http://www.who.int/chp/ steps/2008_STEPS_Lebanon.pdf.
15. Trichopoulou A, Kouris-Blazos A, Wahlqvist ML, Gnardellis C, Lagiou P, Polychronopoulos E, et al. Diet and overall survival in elderly people. BMJ. 1995;311(7018):1457-60.

16. Trichopoulou A, Costacou T, Bamia C, Trichopoulos D. Adherence to a Mediterranean diet and survival in a Greek population. N. Engl. J. Med. 2003; 348(26):2599-608

17. Naja F, Nasreddine L, Hwalla N, Moghames P, Shoaib H, Fatfat M, et al. Association of $\mathrm{H}$. Pylori infection with insulin resistance and metabolic syndrome among Lebanese adults. Helicobacter. 2012;17(6):444-51.

18. Saliba NA, El Jam F, El Tayar G, Obeid W, Roumie M. Origin and variability of particulate matter (PM10 and PM2.5) mass concentrations over an eastern Mediterranean city. Atmos. Res. 2010;97(1-2):106-14.

19. Saliba NA, Kouyoumdjian $H$, Roumie M. Effect of local and long-range transport emissions on the elemental composition of PM10-2.5 and PM2.5 in Beirut. Atmos. Environ. 2007:41(31):6497-509.

20. Levin ML. The occurrence of lung cancer in man. Acta Unio Int. Contra Cancrum. 1953:9(3):531-41.

21. Hanley JA. A heuristic approach to the formulas for population attributable fraction. J. Epidemiol. Community Health. 2001:55(7):508-14.

22. Globocan 2012: Estimated cancer incidence, mortality and prevalence worldwide in 2012 [Internet]. 2016 [cited 26 April 2016]. Available from: http://globocan.iarc.fr/Pages/fact_sheets_population.aspx.

23. The Institute of Health Management and Social Protection (2012). National Health Statistics report in Lebanon. Beirut, Lebanon [26 April 2016]. Available from: http://www.igsps.usj.edu.lb/docs/recherche/recueil12en.pdf.

24. Kobeissi LH, Yassine IA, Jabbour ME, Moussa MA, Dhaini HR. Urinary bladder cancer risk factors: a Lebanese case- control study. Asian Pac. J. Cancer Prev. 2013;14(5):3205-11.

25. Tessier JF, Nejjari C, Bennani-Othmani M. Smoking in Mediterranean countries: Europe, North Africa and the Middle-east. Results from a co-operative study. The international journal of tuberculosis and lung disease : the official journal of the International Union against Tuberculosis and Lung Disease. 1999:3(10):927-37.

26. Jones Nielsen JD, Laverty AA, Millett C, Mainous AG 3rd, Majeed A, Saxena S. Rising obesity-related hospital admissions among children and young people in England: national time trends study. PLoS One. 2013:8(6):e65764

27. Bhaskaran K, Douglas I, Forbes H. Dos-Santos-Silva I, Leon DA, Smeeth L. body-mass index and risk of 22 specific cancers: a population-based cohort study of 5.24 million UK adults. Lancet. 2014;384(9945):755-65.

28. Cheraghi Z, Poorolajal J, Hashem T, Esmailnasab N, Doosti IA. Effect of body mass index on breast cancer during premenopausal and postmenopausal periods: a meta-analysis. PLoS One. 2012;7(12):e51446.

29. Xia X, Chen W, Li J, Chen X, Rui R, Liu C, et al. Body mass index and risk of breast cancer: a nonlinear dose-response meta-analysis of prospective studies. Sci. Rep. 2014;4:7480.

30. Thune I, Furberg AS. Physical activity and cancer risk: dose-response and cancer, all sites and site-specific. Med. Sci. Sports Exerc. 2001:33(6): S530-S50.

31. Kruk J, Czerniak U. Physical Activity and its relation to cancer risk: updating the evidence. Asian Pac J Cancer P. 2013;14(7):3993-4003.

32. Benetou V, Trichopoulou A, Orfanos P, Naska A, Lagiou P, Boffetta P, et al. Conformity to traditional Mediterranean diet and cancer incidence: the Greek EPIC cohort. Brit J Cancer. 2008;99(1):191-5.

33. World health Organization. Global health risks: mortality and burden of disease attributable to selected major risks. 2009. Available from http:// www.who.int/healthinfo/global_burden_disease/GlobalHealthRisks_report_ full.pdf. Accessed 3 May 2016.

34. Trichopoulou A, Martinez-Gonzalez MA, Tong TY, Forouhi NG, Khandelwal S, Prabhakaran D, et al. Definitions and potential health benefits of the Mediterranean diet: views from experts around the world. BMC Med. 2014;12:112. Accessed 3 May 2016.

35. Donaldson MS. Nutrition and cancer: a review of the evidence for an anti-cancer diet. Nutr. J. 2004;3:19.

36. Parkin DM. The global health burden of infection-associated cancers in the year 2002. Int J Cancer 2006;118(12):3030-3044.

37. Wroblewski LE, Peek RM Jr, Wilson KT. Helicobacter pylori and gastric cancer: factors that modulate disease risk. Clin. Microbiol. Rev. 2010;23(4):713-39.

38. Wroblewski LE, Peek RM Jr. Helicobacter pylori in gastric carcinogenesis: mechanisms. Gastroenterol. Clin. N. Am. 2013;42(2):285-98.

39. Daher N, Saliba NA, Shihadeh AL, Jaafar M, Baalbaki R, Shafer MM, et al. Oxidative potential and chemical speciation of size-resolved particulate 
matter (PM) at near-freeway and urban background sites in the greater Beirut area. Sci. Total Environ. 2014;470-471:417-26.

40. Hamra GB, Guha N, Cohen A, Laden F, Raaschou-Nielsen O, Samet JM, et al. Outdoor particulate matter exposure and lung cancer: a systematic review and meta-analysis. Environ. Health Perspect. 2014;122(9):906-11.

41. Naja F, Hwalla N, Itani L, Baalbaki S, Sibai A, Nasreddine L. A novel Mediterranean diet index from Lebanon: comparison with Europe. Eur. J. Nutr. 2014;

42. Gandini S, Botteri E, lodice S, Boniol M, Lowenfels AB, Maisonneuve P, et al. Tobacco smoking and cancer: a meta-analysis. International journal of cancer Journal international du cancer. 2008;122(1):155-64.

43. van Osch FH, Jochems SH, van Schooten FJ, Bryan RT, Zeegers MP. Quantified relations between exposure to tobacco smoking and bladder cancer risk: a meta-analysis of 89 observational studies. International journal of epidemiology. Int. J. Epidemiol. 2016 Apr 20 [Epub ahead of print].

44. Turati F, Tramacere I, La Vecchia C, Negri E. A meta-analysis of body mass index and esophageal and gastric cardia adenocarcinoma. Annals of oncology : official journal of the European Society for Medical Oncology / ESMO. 2013;24(3):609-17.

45. Dai Z, Xu YC, Niu L. Obesity and colorectal cancer risk: a meta-analysis of cohort studies. WJG. 2007;13(31):4199-206.

46. Rui R, Lou J, Zou L, Zhong R, Wang J, Xia D, et al. Excess body mass index and risk of liver cancer: a nonlinear dose-response meta-analysis of prospective studies. PLoS One. 2012;7(9):e44522.

47. Aune D, Navarro Rosenblatt DA, Chan DS, Vingeliene S, Abar L, Vieira AR, et al. Anthropometric factors and endometrial cancer risk: a systematic review and dose-response meta-analysis of prospective studies. Annals of oncology : official journal of the European Society for Medical Oncology / ESMO. 2015.

48. Jenabi E, Poorolajal J. The effect of body mass index on endometrial cancer: a meta-analysis. Public Health. 2015;129(7):872-80.

49. Wang F, Xu Y. Body mass index and risk of renal cell cancer: a doseresponse meta-analysis of published cohort studies. International journal of cancer Journal international du cancer. 2014;135(7):1673-86.

50. Aune D, Greenwood DC, Chan DS, Vieira R, Vieira AR, Navarro Rosenblatt DA, et al. Body mass index, abdominal fatness and pancreatic cancer risk: a systematic review and non-linear dose-response meta-analysis of prospective studies. Annals of oncology : official journal of the European Society for Medical Oncology / ESMO. 2012;23(4):843-52.

51. Poorolajal J, Jenabi E, Masoumi SZ. Body mass index effects on risk of ovarian cancer: a meta- analysis. Asian Pac. J. Cancer Prev. 2014;15(18):7665-71.

52. Wu Y, Zhang D, Kang S. Physical activity and risk of breast cancer: a metaanalysis of prospective studies. Breast Cancer Res. Treat. 2013;137(3):869-82.

53. Keimling M, Behrens G, Schmid D, Jochem C, Leitzmann MF. The association between physical activity and bladder cancer: systematic review and meta-analysis. Br. J. Cancer. 2014;110(7):1862-70.

54. Behrens G, Jochem C, Keimling M, Ricci C, Schmid D, Leitzmann MF. The association between physical activity and gastroesophageal cancer: systematic review and meta-analysis. Eur. J. Epidemiol. 2014;29(3):151-70.

55. Boyle T, Keegel T, Bull F, Heyworth J, Fritschi L. Physical activity and risks of proximal and distal colon cancers: a systematic review and meta-analysis. J. Natl. Cancer Inst. 2012;104(20):1548-61.

56. Buckland G, Agudo A, Lujan L, Jakszyn P, Bueno-de-Mesquita HB, Palli D, et al. Adherence to a Mediterranean diet and risk of gastric adenocarcinoma within the European prospective investigation into cancer and Nutrition (EPIC) cohort study. Am. J. Clin. Nutr. 2010;91(2):381-90.

57. Bamia C, Lagiou P, Buckland G, Grioni S, Agnoli C, Taylor AJ, et al. Mediterranean diet and colorectal cancer risk: results from a European cohort. Eur. J. Epidemiol. 2013;28(4):317-28.

58. Buckland G, Ros MM, Roswall N, Bueno-de-Mesquita HB, Travier N, Tjonneland A, et al. Adherence to the Mediterranean diet and risk of bladder cancer in the EPIC cohort study. International journal of cancer Journal international du cancer. 2014;134(10):2504-11.

59. Bagnardi V, Rota M, Botteri E, Tramacere I, Islami F, Fedirko V, et al. Alcohol consumption and site-specific cancer risk: a comprehensive dose-response meta-analysis. Br. J. Cancer. 2015;112(3):580-93.

60. Huang JQ, Sridhar S, Chen Y, Hunt RH. Meta-analysis of the relationship between helicobacter pylori seropositivity and gastric cancer. Gastroenterology. 1998;114(6):1169-79.

\section{Submit your next manuscript to BioMed Central and we will help you at every step:}

- We accept pre-submission inquiries

- Our selector tool helps you to find the most relevant journal

- We provide round the clock customer support

- Convenient online submission

- Thorough peer review

- Inclusion in PubMed and all major indexing services

- Maximum visibility for your research

Submit your manuscript at www.biomedcentral.com/submit
Biomed Central 